Ardhanariswari et al., 2021

Volume 7 Issue 2, pp. 32-47

Received: 27th January 2021

Revised: $8^{\text {th }}$ March 2021, 13 ${ }^{\text {th }}$ April 2021

Accepted: 20 th April 2021

Date of Publication: 17th September 2021

DOI- https://doi.org/10.20319/pijss.2021.72.3247

This paper can be cited as: Ardhanariswari, K. A., Prayudi., Probosari, N. (2021). The Quadro Helix Communication Models Approach in Developing Creative City of Malang. PEOPLE: International Journal of Social Sciences, 7(2), 32-47.

This work is licensed under the Creative Commons Attribution-NonCommercial 4.0 International License. To view a copy of this license, visit http://creativecommons.org/licenses/by-nc/4.0/ or send a letter to Creative Commons, PO Box 1866, Mountain View, CA 94042, USA.

\title{
THE QUADRO HELIX COMMUNICATION MODELS APPROACH IN DEVELOPING CREATIVE CITY OF MALANG
}

\author{
Kartika Ayu Ardhanariswari \\ Faculty of Social and Political Science, Universitas Pembangunan Nasional "Veteran” \\ Yogyakarta, Indonesia \\ kartika_ayu@upnyk.ac.id \\ Prayudi \\ Faculty of Social and Political Sciences, Universitas Pembangunan Nasional "Veteran" \\ Yogyakarta, Indonesia \\ prayudi@upnyk.ac.id \\ Ninik Probosari \\ Faculty of Economics and Business, Universitas Pembangunan Nasional "Veteran" \\ Yogyakarta, Indonesia \\ ninikprobosari73@gmail.com
}

\begin{abstract}
The development of the creative economy as the basis for the city's growth has given rise to a creative city concept. Cities are a vehicle for residents to move, innovate, and be creative. To foster creative behavior in the city economy requires continuous communication and support from all stakeholders, including Government, economic actors, and society. The first parameter of a creative city is that it can develop the potential for a creative economy. Second, there is a role and synergy between the government, academics, business actors, and the
\end{abstract}


community (community). This research aims to produce multi-stakeholder communication models based on the Quadro Helix approach by Malang creative city. This methodology research will be conducted using qualitative methods through in-depth interviews, observation, and Focus Group Discussion (FGD) on government, academics, business actors, society (community). The result found that Communication synergy between the government, business, community, and academics is essential in developing Malang as a Creative City. The quadrohelix stakeholders are united in the creative Economy Committee, which helps formulate a roadmap for Malang as a creative city.

\section{Keywords}

Creative City, Quadro Helix, Multi-Stakeholder, Creative Economy

\section{Introduction}

The concept of a Creative City is a creative response to urban problems or crises faced by several economic globalization cities. The Creative City concept's ideology is to improve the urban environment and promote an inspiring atmosphere for urban people's creative activities. In the idea of a creative city, three essential aspects need to be considered for a city if a city wants to develop into a creative city. They include the growth of the creative economy, the maintenance of a creative class (groups or individuals), and providing an environment conducive to creative development. There is a strong relationship between these three aspects. The creative class plays a role in developing the creative economy where their creativity leads to products with intellectual property that has commercial value. Creative courses also need a conducive and inspiring environment to carry out creative activities and develop innovative products. This relationship is what makes these three aspects important.

The main component of the creative economy is the existence of creative resources based on the creativity that is owned by the community. Human creativity and new ideas are the drivers of economic development and especially innovation. As a psychological activity, creativity, using non-traditional approaches and different thinking, is often associated with originality, discovery, and new ways of dealing with problems. The ethical and sustainable framing, maintenance, and exploitation of human creativity have become a significant issue for economic development linking it to concepts around innovation, design, and entrepreneurship.

Based on local potential as a fundamental advantage and identity, Creative City Development can effectively increase added value and regional competitiveness. Creative City Development must also be understood holistically and not just branding but as an approach to sustainably developing urban areas based on active community participation (bottom-up), 
which encourages competitive economic growth and an alternative solution to urban problems. Simultaneously, sustainability can be achieved by integrating creative economy value chains that include creation-production-distribution-consumption and conservation.

In developing countries, especially in Indonesia, not many cities have applied the creative city strategy into their city development strategy. Bandung is a pioneer in applying creative cities in Indonesia. On the UNESCO website, Bandung becoming City for Design in 2015. Bandung's creative economic activities are based on design, fashion, graphic design (UNESCO,2017). This then inspired other cities in Indonesia to become creative cities and created a Creative City network forum, where this forum was formed in a participatory manner by the community, both at the district/city level and nationally through the Indonesia Creative City Network (ICCN) Indonesia Creative City. Network. The establishment of the ICCN (Indonesia Creative City Network) or the so-called Indonesian Creative City District-City Network has grown as a basis for developing creative cities in Indonesia with collaboration between stakeholders from the government, academics, business people, the creative community and related institutions such as BEKRAF, The Coordinating Ministry for the Economy and the Ministry of Tourism to stimulate the birth and growth of other creative cities in Indonesia

In 2017, Malang City which has joined the Indonesia Creative City Network (ICCN), was officially designated as a role model for the Indonesian Creative City with a leading creative economy sub-sector, namely Game Application and Development by The Creative Economic Agency (Bekraf) of the Republic of Indonesia. Malang City has a tremendous creative economy potential to be developed. This creative economic potential closely correlates with economic development and growth and the improvement of the people's welfare in the city of Malang.

Research around creative and communication cities is scarce. Most of the communication research is carried out around branding and image of creative cities, while research on communication models in the process of developing creative cities does not yet exist. Therefore, this research is very important to provide new insights into the creative city development process. The proposed communication model, however, still needs improvement, for example, considering the impact of communication, or adding a communication goal as the helical concept is developed.

The problem in this research is how the model and strategy of the Quadro helix communication, which is carried out by Malang city as a creative city in its efforts and policies in collaborating and collaborating to build a creative ecosystem. The purpose of this research 
is to produce a multi-stakeholder communication model based on the Quadro Helix approach between academics, business, government, and communities to collaborate and collaborate to build a creative city ecosystem in Malang. The focus area of this research study is Social Humanities, especially in communication science. Regarding preliminary research on creative cities, it is more about creative city branding, so no one has researched the aspects of the communication model between stakeholders in Malang to develop a creative city ecosystem.

\section{Literature Review}

This study's literature review focuses on literature about creative cities and the quadruple helix model's concepts.

\subsection{Creative City}

At the end of the 20th century, creative cities' ideas based on the creative economy's principles were raised with other new approaches to the economy ('knowledge economy,' 'creativity). Landry, Bianchini (1995) were among the first to claim that cities could and had to be more creative to achieve change. One of the reasons for the rise of creative cities' idea was the response to global fight and restructuring among cities transferring global trade conditions to Eastern countries due to a cheap workforce. Thus, as developed countries lost their competitive aspect, creativity, and knowledge-based, high-quality innovation became a crucial societal factor (Hospers, 2003). It was determined that business subjects whose activities and products are based on individual creativity flourish and impact the global culture and the economy. Knowledge and creativity have become the axis for all business activities.

The Creative Economy paradigm emphasizes the value of creativity, knowledge, and accessibility within the development of a country's economy (United Nations, 2008, p.3). The creative economy merges two concepts, i. e. creativity and innovation. Creativity is searching for new ideas, seeing new solutions, and seeing conventional matters differently. Meanwhile, innovation is a way to use creative ideas. In the creative economy, the creator is the main actor and producer of modern and competitive goods. In this paradigm, culture is understood as the most crucial economic factor, i.e., an engine that generates suitable conditions for economic activities to be carried out rather than a mere consequence or a by-product of economic life (Tarptautinių Kultūros Programų Centres, 2009). According to Levickaitė, Reimers (2011, p.84), features of the creative economy are as follows:

1. Use of information creating custom content;

2. Interactivity, a need for whom arises when interactive relations influence consumer and creator of goods; 
3. The creative economy's impact is the highest when used to create organizations' value and manage intellectual capital.

For a city to become a Creative City, Landry suggests that cities can develop urban space as a catalyst for individuals and creative groups to interact with. Urban development is a way to make people more involved by providing places or areas where they can do activities. The Creative City concept entails three essential aspects for a city: the thriving of the Creative Economic, the development of Creative Class (creative groups or individuals), and the provision of a conducive environment for creativity development. There is a relationship between the three aspects; namely, Creative Class plays a role in developing the creative economy where they are the ones who are creative to produce products in the form of intellectual property that has commercial value. The school needs a safe and effective environment in which they can perform creative activities without fear. An environment that is supportive of creativity and economic advancement needs to be created. Our purpose is the relationship between these three aspects. Summing up the definitions of creative cities provided in scientific literature, the following three prominent positions can be distinguished:

1. Creative cities depend on creativity as the basis for their success. Creative cities hold the reputation of managing their problems well (transport, environmental protection, and others). The leading solutions for improving creative cities are enhancing city life and urban administration (Landry, 2000).

2. Creative cities use the creative arts as a way to improve sustainability through innovation. This idea in the discussion elaborates on the creative sector further. Creativity is essential in the development of cultural innovations and products. Solutions to increase a creative city's competitiveness include specific territorial changes, political actions based on a city's growth of culture, and other creative activities that determine a city's vitality and competitiveness (Pratt, 2008; Department of Culture, Media and Sport).

3. Creative cities have the goal of continuing to attract talent. A creative city is based upon the idea that creative types love it here (qualified and innovative individuals). Creativity in a city can be associated with creativity in an economy because of the knowledge and skills required to create added value and competitiveness (Florida, 2002).

Smith and Warfield (2006) distinguish two orientations of creative cities - orientation towards culture or direction towards the economy. Depending on their orientation, different values can be indicated (Table 1). According to cultural orientation, creative cities are perceived as a locality with robust and flourishing art and culture, creative expression, art, try, and imagination. Meanwhile, the second conception describes the city as a locality with 
innovation, creativity, competitive cultural and creative industries, economic stability, and art organizations. Orientation towards the economy sees creativity as a means to achieve economic goals and development (Smith, Warfield, 2006, pp.3-5).

An essential factor that determines the economic benefit of creative cities is the creativity use opportunity. Creative methods are used differently in different municipalities. For example, creative methods introduce cultural heritage or cultural performances, visual art, and festivals. Because of the importance of creative cities, demand for careers in arts and culture has risen. The city has health benefits and diverse cultural identity.

Table 1: Orientations of Creative Cities

\begin{tabular}{|c|c|c|}
\hline $\begin{array}{c}\text { Orientations of creative } \\
\text { cities }\end{array}$ & Orientation towards culture & $\begin{array}{c}\text { Orientation towards } \\
\text { economy }\end{array}$ \\
\hline Values of creative cities & $\begin{array}{c}\text { Main Values: art, culture, } \\
\text { and well-being of } \\
\text { community, accessibility, } \\
\text { and inclusion. }\end{array}$ & $\begin{array}{c}\text { Main values: sustainability } \\
\text { of city economy and well- } \\
\text { being through creative } \\
\text { industries. }\end{array}$ \\
\hline Definition of creative cities & A place of integral art and \\
& culture. & $\begin{array}{c}\text { A place of economic } \\
\text { innovation, creative talents, } \\
\text { and creative industries. }\end{array}$ \\
\hline
\end{tabular}

(Source: Smith, R., Warfield, K. 2006. The Creative City: A Matter of Value, p.3.)

The Creative Industries Task Force of DCMS is defined as follows: "Industries derived from the utilization of creativity, skills and individual talents to create welfare and employment through the creation and utilization of the creative and creative power of the individual." (Development of Indonesia's Creative Economy 2025, 2008: 4). In true Indonesia style, creative cities have consistently and strategically worked to establish a robust Quadro-helix partnership (Government, community, nonprofit, and private) and plan to include media as a fifth partner. Moreover, it has built a strong partnership with the Government and community functions with total independence.

\subsection{The Concept of Quadruple Helix's}

In the era of decentralization, each region has autonomy and is responsible for developing its area according to its resources (resource-based). We need to plan a development strategy based on innovation policy because innovation is recognized as the driver of economic growth and development. Quadruple Helix's innovation model is an innovation model that emphasizes cooperation between four elements: local government / public authority, industry; 
University/education system; and community/users. The four elements work together dynamically and form an overlapping helix toward the development of the region. The Quadruple Helix model can be used as a regional innovation model with a customization concept adapted to the existing resource conditions in the area itself.

The triple helix concept has been developed by integrating different academicians, entrepreneurs, government, and civil society into an activity based on creativity and knowledge (Oscar, 2010). Etzkowitz \& Dzisah (2008) asserted that the triple helix is driven by the belief that universities operate as bridges between public and private, government, and industry. Higher education institutions are present worldwide and can adapt to fulfil a diverse range of roles. While in the Quadro helix model, producing creativity and innovation requires government, academicians, entrepreneurs, and the public. Mulyana proposes a quadruple helix as a way to develop creativity and design for the creative industry.

According to Fernando (2012), encouraging innovation through creativity and innovation leads to better performance. Today, innovation and research benefit from the changing and interleaving relationships between academics, government, and industry: innovation is a more systemic process, with an accent on effective coordination of a system in which high skills are diffused in various fields (Porlezza \& Colapinto, 2012). The paper discusses the importance of involving government, education, and business in the process to be performed effectively and efficiently. Praswati (2017) found that the concept of quadruple helix contributes to the innovation process in the industry, university, government, and civil society and that the four sectors would interact with each other to accelerate the transfer of innovation.

The quadruple helix model is a theoretical framework that depicts the collaborative relationship between education, industry, government, and community. Every actor has a role and an identity, i.e., the university acts as the researcher (science), the government acts as the policymaker (policy), the industry serves as the producers (economy), and the community works to fit the gap between those three parties (connector). The four-pillar organizations are more innovative and robust competitive because they focus on their distinct goals. First, they allow involved institutions to communicate with one another. Second, they connect institutions to vast and diverse knowledge resources and opportunities. Third, they facilitate collegiate and governmental development of new products, services, processes, and capabilities involving universities and the private sector. 


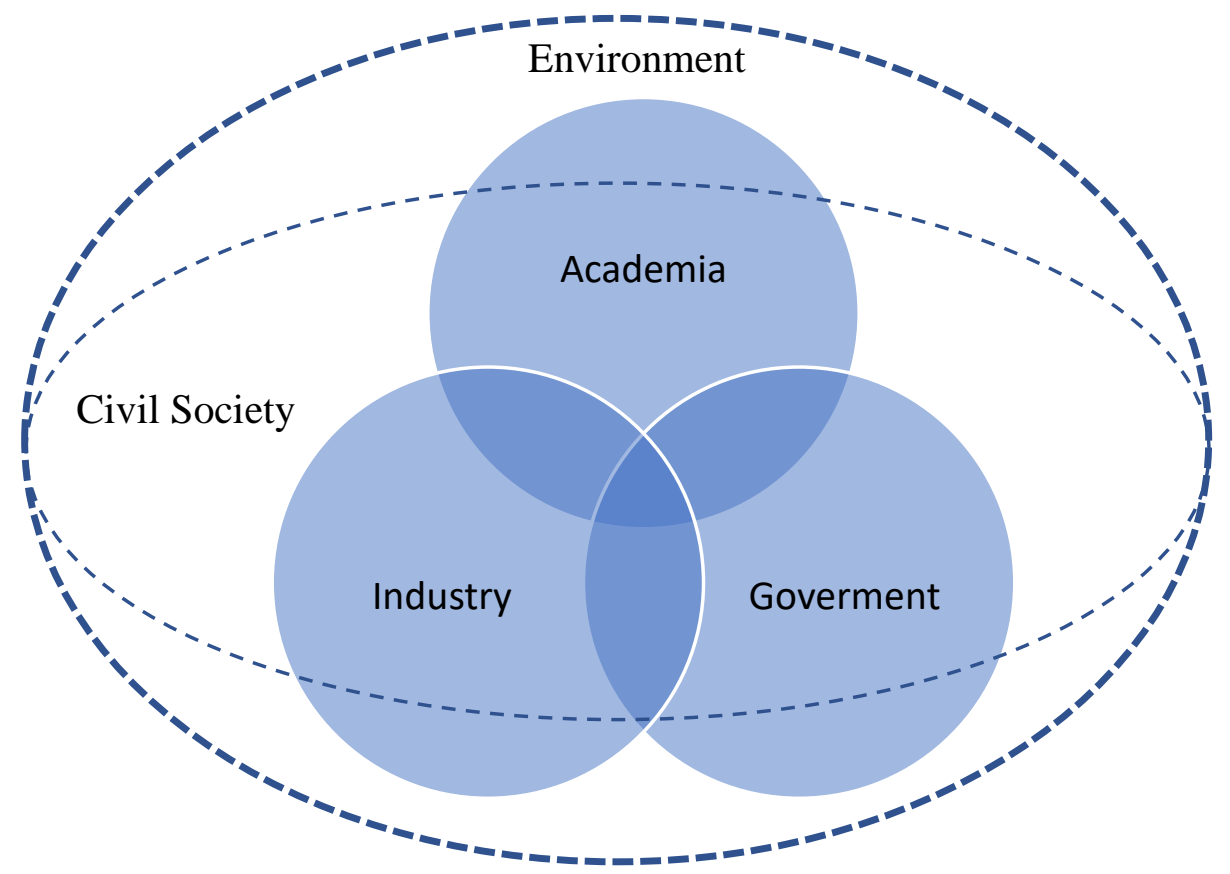

Figure 1: The Quadruple Helix Innovation Model

(Source: Elias G. Carayannis - Carayannis, Elias G.; Barth, Thorsten D.; Campbell, David F. J. (2012-08-08). "The Quadruple Helix innovation model" Journal of Innovation and

\section{Entrepreneurship.)}

And finally, in some cases, nonprofit organizations on behalf of their private sector stakeholders (Dalziel, 2005). Ranga \& Etzkowitz (2013) found that the importance of the relationships between actors in the helix system has now grown an era of innovation where the linkages between actors, i.e., academician, government, business sector plus civil society, will result in new ideas of a high level of innovative products and services. Furthermore, related to the Quadruple Helix (QH) innovation theory, Afonso et al. (2017) state that an innovation economy is based on four helices, i.e., academician, citizens, firms, and government, and their interactions. We believe that the $\mathrm{QH}$ conceptualized the relationship between these four helices, and their collective impact on economic growth deserves to be conveyed and demonstrated mathematically. We develop a one-sector idea-based growth model with complementaries between intermediate goods and services and productive public expenditure. With an idea-based growth model, we can identify innovation as the primary source of economic growth.

\section{Research Methodology}

This methodology research will be conducted using qualitative methods through indepth interviews, observation, and Focus Group Discussion (FGD) on government, academics, 
business actors, society (community). FGD used the descriptive qualitative method, which became the basis for observing and analyzing the creative economic potential closely correlates with economic development and growth and improving the people's welfare in the city of Malang. The data were obtained from the Malang Creative Fashion Community, ICCN Malang PMK3I Malang, ADGI Malang, Game-dev, Academics from the University of Malang, and BAPPEDA Government of Malang. This FGD was held three times, the first with the community and business actors, the second with academics, and the last one with the Regional Device Work Unit in the city government of Malang.

This research focuses on the potential that can be activated from the creative business in the creative economy sub-sector in Malang. The research team chooses the research object and involves the market structure and behaviour in the creative economy sub-sector in Malang. This is done to help determine the choice of strategies and policies that the city of Malang should run in developing creative businesses involving various stakeholders in the city of Malang. The unit of analysis in this study consists of several parties involved in decision making related to the development of the creative business, which includes several Regional Device Work Unit in the city government of Malang and the parties involved in the implementation of these policies that are in the city of Malang such as creative community, universities, and business.

\section{Results And Discussion}

The results of this study have several findings, there is the analysis of Malang as a Creative City Sub Sector of Applications and Games, and The Quadro Helix Communication Models Approach in Developing Creative City of Malang

\subsection{Malang as Creative City Sub Sector of Applications and Games}

Malang City has a tremendous creative economy potential to be developed. Malang has excellent potential in the development of the applications and games subsector. This is evidenced by the growth and development of the applications and games sub-sector since 2002, which began with the opening of departments related to Information Technology in Malang's several universities. Based on sampling data from the independent assessment of creative cities in Indonesia (PMK3I) in 2017 there are more than 4,800 undergraduate graduates with majors related to the application and game sub-sector, and there are 92 studio/startup companies in Malang. In the last two years, there are 151 companies. Industrial growth in the gaming and application sector sub-sector positively impacts the people's economy and labour absorption. Until now, data from the Malang City Government stated that the game and application sub- 
sector were able to absorb more than 2,200 workers, 624 linear personalities, and were active in this field. Game products, such as Panic, Paw Paw, Kimo Run, Galactic Rush, and digital entertainment media startup Kapanlagi Network were born and built in Malang (Kemenparekraf, 2017)

The basis for selecting which indicator will be used in this study is the essence of some studies' indicators. Sources of the indicators used have been prepared by the Creative City Team of Malang, the Malang stakeholder, currently known as a quadruple helix, between university, industry, government, and community. Malang City has great creative economy potential to be developed. Malang has excellent potential in the development of the applications and games subsector. Industrial growth in the gaming and application sector sub-sector positively impacts the people's economy and labour absorption. Until now, data from the Malang City Government stated that the game and application sub-sector were able to absorb more than 2,200 workers, 624 linear personalities, and were active in this field. Three application development studios in Malang are named Inagata, Algostudio, and Beon. Meanwhile, the three development studios are Magesoft, Simpleton, and Algostudio. While Malang communities engaged in the application and game sub-sectors netted in Malang Creative Fusion, such as Station-Startup Malang City, Front-end dev, Malang JS, INDUX, PHP Malang, Mobile Class, Game Dev.

\subsection{The Quadro Helix Communication Models Approach in Developing Creative City of Malang}

The Quadruple Helix (Government, Academics, Community, and Business) discourse, the government's policy in creative economic development, involves communities supporting increased creative resources. Thoughtfully creative urban growth can contribute more to the city's economy to help meet financing needs. If all plans are carried out seriously, it will have an impact on welfare.

With the network it has built, Malang Creative Fusion can also directly convey ideas to the technical office, noting that the ideas benefit the community and improve public services. Developing partnerships also provide opportunities for Malang Creative Fusion to find out about Malang City Government programs so that the concept of Malang Creative Fusion can be synergized. Malang Creative Fusion carries out an effort that is no less important to collaborate directly with the community. Every creative program/activity initiated by Malang Creative Fusion provides benefits that the community can feel directly, thus obtaining support for Malang's creative city. 
Malang Creative Fusion is a cross-community forum/business people as a forum for collaboration between sub-sectors and to make a social contribution to the populist economy. MCF also networks with the ICCN Indonesia Creative City Network), a collaborative forum between urban communities and creative districts throughout Indonesia. Again, this association of creative people is to provide inspiration and input to develop the characteristics of each region's creative economic potential. The MCF community has nearly 300 communities and business people from 16 creative sub-sectors. In addition to actively holding creative sub-sector collaborative activities, MCF seeks to encourage the government to issue various policies through regulations to create a sustainable creative economy in Malang. Businesspeople's role in developing Malang as a creative city is that they are investors, provide access to capital, carry out CSR activities, and support events in the creative economy. Business actors who support, for example, BUMN make "Rumah Kreatif", Telkom Indonesia, BRI, BNI, and others

As one of the cities of education in East Java, universities and academics' role in supporting the creative city of Malang in the apps and games sub-sector is quite significant. Universities that contribute to workforce graduates whom the industry can absorb, the university's role here is to prepare human resources that are following the qualifications needed by the industry. Apart from that, the universities' role is to compile a curriculum based on what is required by the industry. Collaboration and communication are established by cooperating with the MOU and various kinds of events/workshops/conferences in the creative economy with the community, business, and government.

Building a creative city, of course, requires a creative process from city management. Therefore, the government is expected to carry out city arrangement that genuinely reflects the Creative City, for example by providing facilities for creative spaces, guiding community communication as a creative space and building other supporting infrastructure. Thus, Malang City Government must continue to work together by utilizing Malang Creative Fusion's creative ideas to apply them in the policy.

Support of Malang Mayor Regulation Number 12 of 2018 concerning the Road Map for the Development of the Creative Economy in the Leading Sub-Sector and the Priority SubSector of Malang City in 2018-2022. The Regional Government shows an attitude consistent with the government's commitment by formulating plans and taking coherent strategic steps to realize the mission of making the creative economy the axis of its regional economy. A road map for the Creative Economic Development of Malang City has been compiled to develop the Creative Economic in Malang City as one of the Government programs, both in the leading and priority sub-sectors. 
The purpose of establishing this Mayor Regulation is as a guideline for the Regional Government, Universities in Malang City, Malang City Creative Economic Community, and Malang City Creative Economic Sub-Sector Business Actors to develop the creative economy Malang City. The Road Map of Creative Economy Development aims to provide direction for the implementation of creative economy development both within the Regional Government, Higher Education, Creative Economy Community, and Creative Economy sub-sector business actors so that activities that have been agreed upon can run effectively, efficiently, consistently, and integrated. It also supports accelerating the achievement of the Regional Government's vision and mission as stated in the Regional Medium Term Development Plan (RPJMD). The development of Creative Economics in Malang City is a demand in terms of government policies and the conditions and dynamics of Malang City people, increasing regional competitiveness. So, it is necessary to formulate an implementation guide in the form of programs and activities that are measurable and can be implemented by all the supporting components in it.

Table 2: Roles of Quadruple Helix Actors in the Development of Malang as the Creative City

\begin{tabular}{|c|c|c|c|}
\hline Academics/University & Community & Business & Government \\
\hline 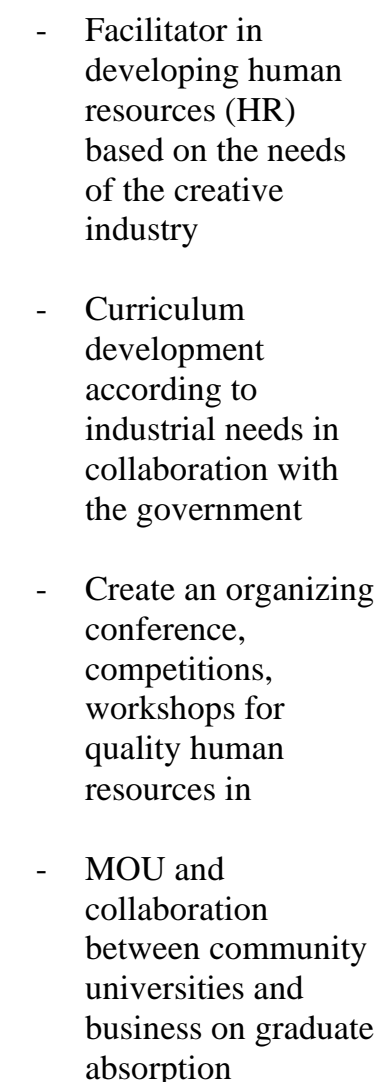 & $\begin{array}{l}\text { - Facilitator as well as } \\
\text { liaison between } \\
\text { business } \\
\text { actors/communities } \\
\text { with local } \\
\text { governments and } \\
\text { universities in the } \\
\text { context of developing } \\
\text { the creative economy } \\
\text { - Organizing a creative } \\
\text { event/workshop } \\
\text { festival }\end{array}$ & $\begin{array}{l}\text { - The object of creative } \\
\text { economy development } \\
\text { actors who collaborate } \\
\text { and synergize with } \\
\text { other supporting } \\
\text { components (Local } \\
\text { Government, } \\
\text { Academics / } \\
\text { Universities and } \\
\text { Communities } \\
\text { - Provide access to } \\
\text { capital, carry out CSR } \\
\text { activities, and support } \\
\text { event in the realm of } \\
\text { the creative economy }\end{array}$ & $\begin{array}{l}\text { - Issue regulations and } \\
\text { policies related to } \\
\text { the development of } \\
\text { the creative economy } \\
\text { - Forming a "Komite } \\
\text { Ekonomi Kreatif" } \\
\text { (KEK) which helps } \\
\text { formulate a roadmap } \\
\text { for Malang as a } \\
\text { creative city } \\
\text { - Facilitator and } \\
\text { initiator of creative } \\
\text { economy } \\
\text { development } \\
\text { - Facilitator of } \\
\text { Intellectual Property } \\
\text { Ownership for } \\
\text { creative economy } \\
\text { actors } \\
\text { - Infrastructure } \\
\text { provider for craft } \\
\text { actors }\end{array}$ \\
\hline
\end{tabular}

(Source: Data Processing, Analysis, and Interpretation) 
Communication synergy between the government, business, community, and academics are essential in developing Malang as a Creative City. Based on the studies that have been conducted, an analysis can be obtained to strengthen collaboration in realizing the ideal creative city. To generate greater collective power in the Malang Creative Fusion forum, we can take advantage of untapped creativity potentials. This is beneficial for the regeneration and sustainability of the organization. As an organization, Malang Creative Fusion can expand, generate an economy so that the financing does not depend on the government or private institutions

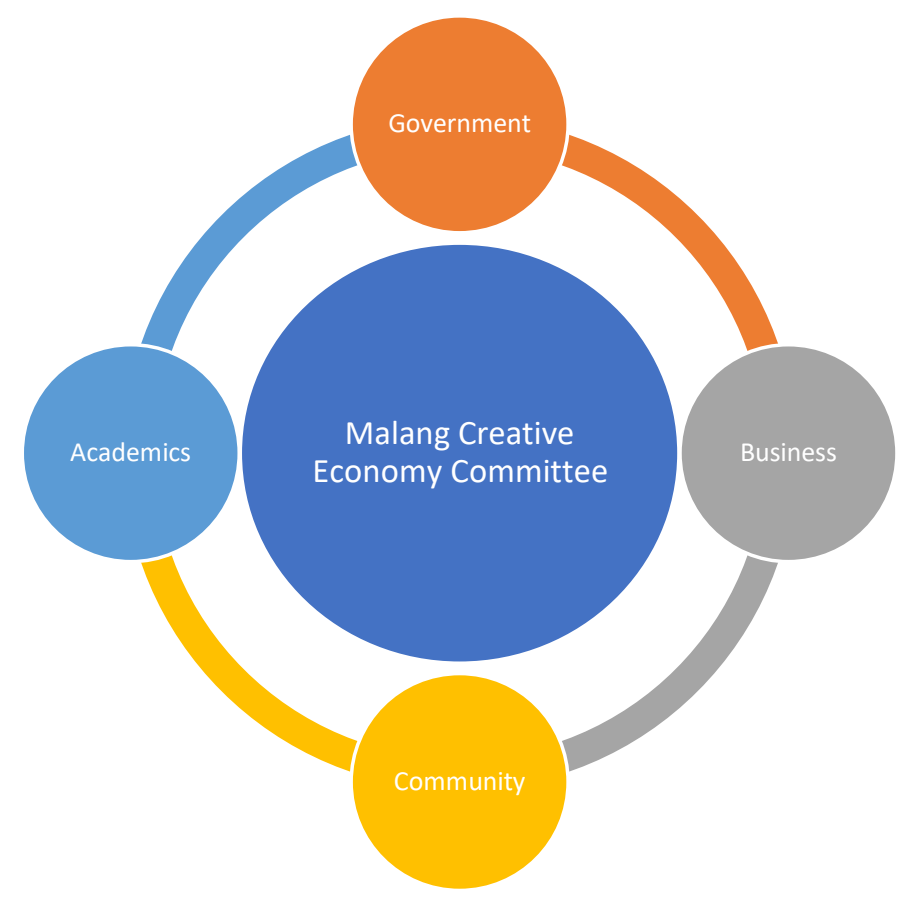

Figure 2: The Quadruple Helix Communication Model in Malang as Creative City

(Source: Data Processing, Analysis, and Interpretation)

Normatively, the Malang City Government provides a means that allows all city stakeholders to participate in the development by submitting proposals for programs/activities that the APBD will fund through the Planning Consultationutilized based on the support of Malang Mayor Regulation No.12 of 2018 concerning the Development Road Map the Creative Economy of the Leading Sub-Sector and the Priority Sub-Sector of Malang City 2018 - 2022. The Regional Government shows a consistent attitude with the government's commitment by compiling plans and taking coherent strategic steps to realize the mission of making the creative economy the axis of its regional economy. To develop the Creative Economic in Malang City as one of the Government programs, it has compiled a road map for the Creative Economic Development of Malang City, both in the leading sub-sectors and priority sub-sectors. The purpose of establishing this Mayor Regulation is as a guideline for the Regional Government, 
Higher Education in Malang City, Malang City Creative Economic Community, and Malang City Creative Economic Sub-Sector Business Actors to develop the creative economy Malang City.

\section{Conclusion}

This research results answer the purpose of this research is to produce a multistakeholder communication model based on the Quadro Helix approach between academics, business, government, and communities to collaborate and collaborate to build a creative city ecosystem in Malang and search for primary research data through in-depth interviews with several sources who are the key actor.

This research provides a framework for improving innovation performance through the increased creative city by applying an approach and interaction of a quadruple helix model. In this framework, creativity is an essential element in improving innovation in the creative city in Indonesia. This framework recommends creating innovation performance in the creative city to enhance creativity and competitive advantage through the contribution and interaction between university, business, government, and civil society. According to the preliminary study, it can be concluded that performance in the creative city is produced from excellent creativity supported by valuable contribution and interaction between university, business, government, and civil society in a quadruple helix model.

The scope of future research related to creative cities is, for example linking the concept of communication synergy between stakeholders in building branding in creative cities or how communication between creative city networks is mutually reinforcing. Meanwhile, our research has limited communication between shareholders in building a creative city ecosystem in Malang.

\section{Acknowledgements}

The authors thank the Ministry of Research, Technology, and Higher Education of the Republic of Indonesia for providing funds for this research. Our gratitude also goes to the Institute for Research and Community Service at Universitas Pembangunan Nasional "Veteran" Yogyakarta, Indonesia, for helping us complete administrative matters. Malang Creative Fushion Community, ICCN Malang, PMK3I Malang, ADGI Malang, Game-dev, Academics University of Malang, and BAPPEDA Government of Malang. 


\section{REFERENCES}

Carayannis, EG \& Campbell D.F.J. (2006). Knowledge Creation, Diffusion and Use in Innovation Network and Knowledge cluster: A Comparative System Approach Across the United States, Europe, and Asia. Praeger.

Dalziel, M., (2005). A Report Prepared for the Prime Ministers Advisory Council on Science and Technology Government of Canada, Canada. School of the Management University of Ottawa.

Etzkowitz, H \& Dizisah, J. (2008). Triple Helix Circulation: The Heart of Innovation and Development. International Journal of Technology Management and Sustainable Development, 7(3), 101- 115. https://doi.org/10.1386/ijtm.7.2.101_1

Florida, Richard. (2002). The Rise of the Creative Class: And How It's Transforming Work, Leisure, Community, and Everyday Life. New York: Basic Books, 404p.

Hospers, Gert-Jan. (2003) Creative Cities in Europe: Urban Competitiveness in the Knowledge Economy. Intereconomics, ISSN 0020-5346, Vol. 38, Iss. 5, pp. 260269, https://doi.org/10.1007/BF03031728

Kemenparekraf. (2017). Profil Kota/Kabupaten Kreatif Malang, available at https://kotakreatif.kemenparekraf.go.id/wp-content/uploads/2020/09/1.-KotaMalang.pdf

Landry, Charles. (2008). Creative City: A Toolkit for Urban Innovation. London: Earthscan. Mulyana, Sutapa. (2014). Peningkatan Kapabilitas Inovasi, Keunggulan Bersaing dan Kinerja melalui Pendekatan Quadruple Helix: Studi pada Industri Kreatif Sektor Fashion. Jurnal manajemen Teknologi, Vol. 13, No. 3. https://doi.org/10.12695/jmt.2014.13.3.5

Oscar. A., S. Monterino., \& M. Thomshon. (2010). A Growth Model for the Quadruple Helix Innovation Theory. Journal of Business Economics and Management, 13(4), 1-31.

Porlezza, C. and Colapinto, C. (2012). Innovation in Creative Industries: From the Quadruple Helix Model to the Systems Theory. Journal of the Knowledge Economy, 3(4), pp. 343-353. https://doi.org/10.1007/s13132-011-0051-x

Pratt, Andy C. (2008). Creative Cities: The Cultural Industries and The Creative Class. Geografiska annaler: Series B - Human geography, 90 (2). pp. 107-117. https://doi.org/10.1111/j.1468-0467.2008.00281.x

Richard Smith and Katie Warfield. (2000). The Creative City: A Matter of Values. in Philip Cooke \& Luciana Lazzeretti (ed.), Creative Cities, Cultural Clusters and Local 
Economic Development, chapter 12, Edward Elgar Publishing, available at https://www.elgaronline.com/view/9781847202680.00021.xml

Smith, R., Warfield, K. (2006). The Creative City: A Matter of Values, available at http://sites.utoronto.ca/isrn/publications/WorkingPapers/Working07/Smith07_Creati veCity.pdf

UNESCO. (2017). Bandung Creative Cities Network, available at https://en.unesco.org/creative-cities/bandung 